\title{
Identity in Life Writing of M.E. Jordan's Balanda: My Year in Arnhem Land as an Alternative Discussion in Pursuing English Literature Learning for EFL College Students
}

\author{
Leni Marlina \\ University Negeri Padang (UNP) \\ Padang, Indonesia \\ lenimarlina_11@unp.ac.id
}

\begin{abstract}
EFL college students in Indonesia mostly tend to analyse classic literary works or Young Adult Literature. Actually they have chance to do an alternative discussion on life writing in literature class, for instance on Marry Ellen Jordan's Balanda: My Year in Arnhem Land (BMYIAL), published in 2008. It is a life writing written based on the author's life experience during her time working for twelve months in the Australian Indigenous people (AIP) community in Maningrida, Arnhem Land, Northern Australia. Redd (2005) claims that the narrative of Jordan's BMYIAL is very evocative. Moreover, the title of BMYIAL shows a provocative term - Balanda. In Jordan's BMYIAL, the term of Balanda literally applies to the non-Indigenous population at Maningrida as described by its Indigenous inhabitants. At the same time, the term of Balanda also situates the author's experiences 'out of place' on a land that she identifies as Aboriginal land. In addition, Jordan's BMYIAL is an interesting life narrative because it alludes two issues: the selfidentity of Balanda's and the cultural identity of Australian Indigenous people (AIP). The aim of this paper is to identify both types of identities and to discuss the influence of Balanda's identity upon AIP's cultural identity as a discussion model for EFL college students.
\end{abstract}

Keywords—component, formatting, style, styling

\section{INTRODUCTION}

Marry Ellen Jordan's book entitled Balanda: My Year in Arnhem Land (BMYIAL) is a life writing written based on its author's life experience during her time working for twelve months in the Australian Indigenous people (AIP) community in Maningrida, Arnhem Land, and Northern Australia [1]. At glance Jordan's BMYIAL is just like other self-life narratives which employs dialogues and monologues [2]. In fact Jordan's BMYIAL captures many impressions and conversations that people may experience when they live for the first time in a remote community. During the time of her struggle living in Maningrida, Jordan has paid attention to her surroundings such as weather, local store, accommodation, ever-present dogs, and local people as constructed in her narrative. I argue that the term of "Balanda" in Jordan's BMYIAL tends to emphasize the sense of self-identity from the perspectives of both Indigenous and non-Indigenous people in Maningrida. Furthermore, I argue that self-identity being Balanda in Jordan's comes from the critical question of Balanda's role in Australian Indigenous people (AIP) community: whether Balandas have important role in protecting AIP's culture or they just do assimilation and cause some issues among AIP community.

Self-identity is a complex multidimensional concept which can be defined in two ways [3]. First, selfidentity is defined as "Who am I?" This means as an integrated image of oneself as a unique person, which often includes ethnic identity. In relation with this, the question "Who am I?" has subjective value and meaning [4]. Second, self-identity is defined as "What one is?" This means as being distinguished from other persons, what one knows and believes, what one holds and reveres, and what meaning one's existence has.

Additionally, the notion of identity is closely linked to self-concept. Self-concept is a term with two components [5]. The first self has two meanings: one is the self as subject or agent (the knower), and the second is the self as object (the known). The other component refers to one's knowledge or beliefs. Altogether, then, the term selfconcept means what an individual knows or believes about oneself. However, the notion of identity is usually considered to go beyond the belief or knowledge that is emphasized in the notion of self-concept. In other words, self-concept and identity are what come to people's mind when they think of themselves, including both personal and social identities.

Furthermore, self and identity are the essentials things which always tied up with human crossing time and space [6]. Human are actors and they always have the possibility of choices such as finding their self-identities. 
Indeed, the self of human functions to maintain someone's identity since it has an inner life and a point of view [7]. Besides, someone's identity is something formed through his interaction with other self-experiences in terms of categories such as race, nationality, gender, age, and sexuality [8]. Similarly, Factors such as race and ethnicity become significant at different times in different ways [9]. By all means, humans never cannot be separated from their self-identity which can be viewed from various factors. To illustrate, the term of race and its culture become significant factors to identify someone's identity in Jordan's BMYIAL.

\section{DISCUSSION}

1. Balanda's Self-Identity

The narrative of Jordan's BMYIAL reveals that all non AIP who have been living in Maningrida find their identity as foreigners or outsiders in the point of view of AIP. This kind of identity looks more obviously when AIP called non AIP as Balanda. The term of Balanda is originally derived from the word used by Macassan (Indonesian) to refer Hollanders in denoting the Dutch colonists of Indonesia. In Maningrida where the Jordan's narrative takes place, Balanda refers to European Australians. Giving name of Balanda to Euro-Australian does not mean that those AIP cannot live purely and independently without the interaction and involvement with the Balandas. Nor, it means that Balandas' community gives no influences or effects upon AIP's community. In fact, Jordan's life narrative reveals her struggle in learning what it means to be a Balanda by raising some issues among AIP which might be as the result of Balanda's interaction and involvement in AIP's community.

In constructive her life writing of $B M Y A L$, Jordan as the life narrator employs three elements. They are personal memories, personal relationship to subject, and personal observation during working time in AIP's community without. The life narrator does not have a special historical document nor interview a resource person. In fact, Jordan mentions in her author's note that her book is a subjective, personal account - "the story of what it was like for her to live in AIP community" (p.vii). Using personal memory as well as personal account can be used as a technique in creating a life narrative [10].

To demonstrate the use of personal narrative, Jordan tells the readers that her first reason to go to Maningrida is because of "an awareness of how little she knew about Aboriginal cultures and a desire to learn more" (p.25). She observed that like many other white Australians, she knew something of the "complex spirituality", the dreaming and the "deep relationship to the land". Then, Jordan tells the readers that she worked in one of the northernmost parts of Australia as editor for a book on Aboriginal art for the local art centre.

How Jordan as a Balanda got experience since the first time she arrived in Maningrida is just like the common people's experience coming to the new and unfamiliar place; she got experience both in the period of honeymoon and cultural shock. The early time outsiders initially go to indigenous communities, they will get honeymoon period; they are aware of surprise things about the indigenous people [11]. After a few weeks, they will get cultural shock; they start getting conflict between their previously-held beliefs and their new learning values. After passing honeymoon and cultural sock period, Jordan tried to get her determination in understanding herself living in AIP's community by asking "what it means to be a Balanda in Maningrida" (p.9). Consequently, this question is the critical and philosophical one dealing with self-concept and identity.

The self-concept and identity develop out of social or symbolic interaction and are dependent on social interaction for their maintenance [12]. In fact, Balandas' identity in BMYIAL is constructed merely by their less or very little interaction and personal contact with AIP. Most of Balandas will merely have contact with AIP at workteaching, project managing, building or buying and selling (p.8). The reasons of this less interaction from AIP's point of view is that AIP do not understand what Balanda need and how they expect to be treated [13]. Despite of the life narrator of BMYIAL had less interaction with many AIP, she had tried to recognize herself-identity as well as she tried to understand AIP's cultural identity in her narrative.To supper her account, Jordan also listened to what her Balanda friends'comment about living in AIP community, and focalise their friends in her narrative.

Today the meaning of working for Aboriginal people has changed [14]. Aboriginal people employ White staff to "work for" them - in Aboriginal independent schools, in legal services, in health care. The role of nonAboriginal is to implement the policy of the Aboriginal people; White people work for Aboriginal people. In $B M Y I A L$, the life narrators told the readers that this ideal concept could not be found. In contrary, other Balandas in $B M Y I A L$ mentioned that they worked in Maningrida only for money:

'It's good way to make money', they explained. 'You get paid well, and Kath gets a remote living allowance on top of her wage, and it's cheap to live here. We plan to save for a few months and then move on' (p.36).

Moreover, the worst one is that other Balandas in Jordan's BMYIAL tended to be racist by mentioning that Balanda will have an alright time in Maningrida as long as they do not have to mix with the locals (p.36).

To put in another way, Jordan's BMYIAL reveals that Balanda is a self-identity which is not only constructed by Aboriginals for newcomers in northern Australia, but it is also a self-identity which is constructed by newcomers for themselves. 
2. The Cultural Identity of Australian Indigenous People(AIP)

Cultural identity is a short of collective "one true self", hiding inside the many other, more superficial or artificially imposed "selves", which people with a shared history and ancestry hold in common identity [15]. The Indigenous people have self-conscious group identities which are associated more with culture [16]. In addition, Indigenous people know best when it comes to matters of their own identity [17]. Indigenous cultural identity is viewed here as symbolic state and behavioural expression of being an indigenous person [5]. A positive indigenous cultural identity is comprised of a number of interrelated features such as expressing identity in one's daily behaviour. In her effort to understand Australian Indigenous people (AIP)'s culture, Jordan tried to capture anything she got related with events and experiences influencing AIP's cultural identity.

There are many categories and factors influences cultural Identity [5]. However, Jordan's BMYIAL strongly captured AIP's cultural identity in relation with land and environment; family and kinship; ritual ceremony and dances; arts and paintings.

\section{Land and Environment}

For AIP, land is God-given [18]. It is sacred land, highlighted by especially significant sites of spiritual importance. This land is inalienable and its charter is that of the dreaming. Aboriginal man has an incontrovertible right of possession. So, AIP articulates living on the land and feeling the close connection to their traditional cultural activities as central to their cultural identity. Therefore, it was necessary for AIP to live in a close relationship with the physical environment. Most of AIP prefer to live in the wild land than in residential areas because they feel free and comfortable to live there eventually. An outsider might form the impression that Aborigines were parasites upon nature [19]. On the Aboriginal view, however, nature and society were mutually dependent.

\section{Family and Kinship}

Cultural identity of most AIP in rural and remote areas has been primarily a matter of kinship ties associated with their perceived place of origin [20]. Jordan as Balanda observed that the circle meeting on the dust among group of AIP who consist of some kin is a familiar view in Maningrida:

On the streets were Balanda houses, with fences and gardens kept green during the Dry Season with daily watering, alongside Aboriginal houses with no fences, where people sat around a fire outside and the ground was dusty and dry, and dogs lay in cowed heaps on the verandahs (p.16).
In fact, the meeting which involves kinship is an essential thing to identify AIP's cultural identity. The kinship is a kind of metaphor as one of the potent forms of securing identity construction [21]. For Indigenous people, the connection of kin and community shows their cultural identity [22].

\section{Ceremony and Dances}

This connection of Indigenous people with the Dreamtime was maintained through ritual and ceremony, and celebrated and passed on from generation to generation in song, chant, dance and artistic expression, in which all members of the clan participated [23]. Indigenous children learned new lessons through watching the ceremonies that enacted the stories about the ancestral beings that had set down the rules for how people should behave towards each other and the land. The ceremony was held by using special music and dances. One of AIP's dances was described by Jordan an opening ceremony for the first remote Centreline the Australian government's welfare shop front - in Maningrida. The dance was taken from the ancient diplomacy ceremonies practised in AIP's land since long time ago:

This Centrelink is on land owned by the Dkurridji clan and they are going to dance its opening for us. The dance will be taken from the ancient diplomacy ceremonies practised in this region for centuries (p.5).

\section{Arts and Painting}

AIP have always been poets, musicians, singers, dancers, painters, sculptors and weavers. Each person had an artistic role in ceremonies. Today their art thrives in many different forms. Some artists continue to work in traditional ways [24]. In BMYIAL, painting was very popular arts of AIP. Jordan told the readers how the artists especially painters still maintained the use of bark as painting media instead of canvas in order to have high originality and quality of painting:

Bark paintings were either stacked against the walls or arranged on trolleys that looked like giant toast racks. (p.42, pp.1).

Anyone big enough to carry an artwork was taking a sculpture or a bark painting wrapped in an old sheet or blanket out of the car. The centre had a policy of buying every piece of art that was brought in, regardless of its quality, a way of nurturing younger artists, and also supporting the cultural practises of painting on bark, sculpting and weaving (p.42, pp.2). 
The production of paintings was really paid attention by both Balanda and AIP, and perhaps this became the reason why there is Indigenous art centre in Maningrida.

In brief, Jordan's BMYIAL carefully construct the narrative which reveals the cultural identity of AIP through Indigenous' landscape, family, and arts.

3. Issues of Cultural Identity of Australian Indigenous People (AIP)'s Cultural Identity

Acculturation of Indigenous people always gives positive and negative influences; contemporary consequences and long term outcomes [5]. There are many consequences of such acculturation, and one of them is cultural identity. For instance, along the process of understanding both of her self-identity and AIP's cultural identity, Jordan posted several critical questions to herself as well the readers about some issues faced recently by AIP in Maningrida such as crisis of cultural identity; lack of education; low health quality; and drugs and gambling in Arnhem Land. Unlike the rural and remote areas, ideal cultural identity of AIP in Maningrida has changed and begun to breakdown.

As an illustration, there is a steady stream of fast food and soft drink being sold and consumed by AIP who already have more health problems than city folk:

On the way to the shop, my Melbourne eyes were startled by the sight of so many dark faces, all of them the deepest and richest of blackish brown (p.19, pp.2).

When I got there I found a crowd of people with lots of kids and dogs milling around the entrance. ... There was a whole aisle of chips and soft drinks, and a section selling white sugar in $5 \mathrm{~kg}$ tins. There were also huge tins of milk powder and other groceries that keep; canned things and dried things. Along the back wall ere the freezers and fridges, where there were basic dairy products, a small selection of fruit and vegetables, and frozen meat a[nd various frozen foods (p.19, pp.2).

Thus, the life narrator of BMYIAL focalises her experience in a shop to raise a health issues among Indigenous. This helps Jordan to construct her narrative about Aboriginals' cultural identity BMYIAL. To see these changes and breakdowns of cultural identity, the outsiders can start noticing from the shop [25].

Furthermore, many adult aborigines are alcoholics. Inherent metabolic differences in Aborigines as a race, particularly in relation to the body's ability to process sugar and alcohol, are partly responsible for this poor standard of health [23]. Until recently, many urban aboriginal children were suffering from undernourishment to the point of permanent brain damage. This is not due to a lack of food so much as a lack of knowledge about nutrition; an addiction to sugar and carbohydrates to the exclusion of fresh fruit and vegetables. No wonder Jordan highlighted aboriginal kids who danced with soda in hand:

When the action died down and they took a break I watched the kids, in bright American basketball singlets, run to drink from their bottles of Coke and chatter amongst themselves in a language I couldn't understand. It stuck me as the ultimate postmodern scene: an Aboriginal kid with a kangaroo tail in one hand and a bottle of Coke in the other (p.31)

The bottle of coke in the ten-year-old's hand now looked like a symbol of drug addiction, a potent cocktail of caffeine and sugar. Now it reminded me not of a kid having a drink in a globalised community, but of the high rates of diabetes and heart disease in Arnhem Land and place like it, and the early death they caused (73).

Beside issues of health above, she also raised issues of bureaucracy. "She had expected to be surrounded by the exotic, but instead she was enmeshed in white bureaucracy, a jungle of Latinate terms like acquit, triplicate and application" (p.91). As the result, Jordan could not find the things always ran in an AIP's way in Maningrida.

Therefore, Jordan's BMYIAL reveals the change of self-concept of the life narrator. Self-concept is a structural product of reflexive activity, but it is also susceptible to change as the individual encounters new roles, situations, and life transitions [26]. Jordan's reflexive and changeable self-concept toward AIP's cultural identity:

"Before I went to Maningrida, I would have argued that indigenous systems of power and prestige were more important for indigenous people. ... But I didn't work like that, and the Balanda endeavour to protect the Aboriginal communities wasn't working. All sorts of aspects of the dominant culture were creeping into theirs drugs, unhealthy foods, television. ...We needed to think carefully about what it was that we were protecting" (p.218).

What make human beings become special with their identity is that they have ability to interpret and respond the world [27]. In Jordan's BMYIAL, her life narrator tried to position the implied readers to think her interpretation and respond toward AIP's world in Maningrida. She interpreted that based on her Balanda's eyes; the traditional Aboriginal cultures were changing, but not always for the better:

We handed over the things we believed to benign-housing, health care, cars, clothes but with them came drugs, processed food, televisions and guns. We believed that 
Aboriginal cultures would be corrupted by contact with the intellectual aspects of Balanda culture-the English language, literacy and bureaucracy. We had fallen prey to the idea that a thing was just a thing, that it did not come with any culture attached (p.219).

On account of the Indigenous culture change, Jordan gave a response by being frustrated because of her inability to do anything that would actually make things better for Aboriginal people (p.201). To repeat, the life narrator has no alternative solution to overcome the issues. However Jordan responded by posing a question and an idea to herself as well the implied readers:

What are the alternatives? I didn't have any answers. But I wondered whether; if we abandoned the idea that Aboriginal people should simply 'be Aboriginal,' we might be able to work together to come up with a more realistic way of negotiating the constant, complex and inevitable processes of cultural exchange and interaction (p.220).

\section{CONCLUSION AND RECOMMENDATION}

As discussed above, M.E. Jordan's Balanda: My Year in Arnhem Land (BMYIAL) reveals that the life narrator's struggle in learning what it means to be a Balanda in Maningrida, northern Australia. It is found that the meaning of Balanda is a complete thing since it is the result of the perception both of Aboriginals and newcomers. Consequently, in constructing the narrative of her life writing, Jordan depicts detail and careful depiction of her personal memory about the life and the people (both Balandas and Indigenous). For Jordan herself, being a Balanda in Maningrida has challenged her perceptions of race and culture.

The concept of self-identity in Jordan's BMYIAL is constructed based two components. First, self-identity derives from these questions; 'Who am I?', 'Where do I belong?', and 'How do I fit in?' Second, self-identity derives from the way to understand the cultural identity of people where someone lives in. Jordan's BMYIAL, both of these components show that being a Balanda does not only refer to different race from Australian Indigenous people (AIP), but it also means being an agent who may effect cultural changes at AIP's community. To repeat, the narrative of BMYIAL reveals how its author tries to tell the implied readers that it is not enough to come to an Australian Indigenous community with good intentions without considering AIP's culture. All in all, Jordan's BMYIAL is the life writing which combines both description of White Australian self-identity and Aboriginal cultural identity based on the author's personal and subjective account during her time living in Maningrida, Australia.

\section{References}

[1] Jordan, Ellen. 2005. Balanda: My Year in Arnhem Land. Sidney: Alen \& Unwin.

[2] Watson J. and Smith S. 2010.A guide for Interpreting Life narratives: Reading Autobiography. $2^{\text {nd }}$ Edition. London: University of Minnesota Press.

[3] Bailey, Joseph A. 2003. Self- Image, Self-Concept, and Self Identity Revisited. Journal of The National Medical Association. Vol. 95(5): 383-386.

[4] Mascuch, Michael. 1996. Origins of the Individualist Self: Autobiography and Self-Identity. England: Stanford University Press.

[5] Berry, J.W. 1999. Aboriginal Cultural Identity.The Canadian Journal of Native Studies. Vol. XIX (1):136. (Online).Retrieved in August 2011 from www.brandonu.ca/ Library/cjns/19.1/cjnsv19no1_pg136.pdf.

[6] Bamberg, Michael . 2010. Who am I? Narration and Its Contribution to Self and Identity. Journal of Theory \& Psychology. 21(1) 1-22. (Online). Retrieved in July 2011 from <tap.sagepub.com/content/21/1/3.short....>.

[7] Olshen, B. N. 2001. The Self. In M Jolley (ed.). Encyclopaedia of Life Writing. London: Fitzroy Dearborn. Pp. 799-801.

[8] McCooey, David. 2011. Notes on 'Self', 'Subjectivity' and 'Identity'. Online Week notes of Unit ALL783: Life Writing. (Online). Retrieved in August 2011 from http://vista.deakin.edu.au >.

[9] Chaitin, Julia. 2004. My Story, My life, My Identity. International Journal of Qualitative Methods. Vol.3 (4): 1-16.

[10] Smith, S. and Watson J. 2010. "Life Narrative: Definition and Distinction." Reading Autobiography: a Guide for Interpreting Life Narative. Minneapolis: University of Minnesota Press.

[11] Michie, Michael. 2011. Identity Learning, Culture Shock and Border Crossing into Effective Teaching in Indigenous Science Education. Paper presented at the 42nd annual conference of the Australian Science Education research Association, Adelaide SA, $29-2$ July 2011. (Online).Retrieved in August 2011 from $<$ members.ozemail.com.au/ $\sim$ mmichie/identity_cshock.pdf $>$.

[12] Gecas, Viktor. 1991. The Self-Concept as a Basis for a Theory of Motivation. In J.A. Howard (eds.). The SelfSociety Dynamic: Cognition, Emotion, and Action. USA: Cambridge University Press.

[13] Lister, Peter. 2011. The 'Family' Concept and Yolngu/Balanda Relations . (online). Retrieved in July 2011 from http://www.manikay.com/library/yolngu family concept.shtml.

[14] Jordan, Deirddre E. 1986. Aboriginal Identity: The Management of a Minority Group by the Mainstream Society. The Canadian Journal of Native Studies. Vol.VI (2):271-311. 
[15] Hall, Stuart. 1990. Cultural identity and Diaspora. In J. Rutherford (ed.). Identity: Community, culture, Difference. London: Lawrence \& Wishart. pp. 222237.

[16] Stokes, Geoffrey . 1997. Citizenship and Aboriginality: Two Conceptions of Identity in Aboriginal Political Thought. The Politics of Identity in Australia. United Kingdom: Cambridge University Press.

[17] Morton, John. 1998. Essentially Black, Essentially Australian, Essentially Opposed: Australian Anthropology and Its Uses of Aboriginality Identity. In HurgWassman (ed.). Pacific Answers to Western Hegemony. USA: Oxford International Publisher (Berg).

[18] Bernt, Ronald M. 1992. The World of First Australian. Canberra: Aboriginal Studies Press.

[19] Maddock, Kenneth. 1974. The Australian Aborigines: A Portrait of Their Society. Victoria: Penguin Book Australia Ltd.

[20] Yamanouchi, Yuriko . 2011. Kinship, Organisations and 'wannabes': Aboriginal Identity Negotiation in South-western Sydney. Paper.Osaka University of Economics and Law.(Online).Retrieved in July 2011 from www.asianlang.mq.edu.au/Oceania 802 Art6.pdf.

[21] Schopflin, George. 2001. The Construction of Identity. (Online). Retrieved in August 2011 from (www.oefg.at/text/veranstaltungen/wissenschaftstag/... /Beitrag_Schopflin.pdf).

[22] Demosthenous, C. and friends. 2006. Cultural Identity and Financial Literacy: Australian Aboriginal Experiences of Money and Money Management. Paper presented to the Financial Literacy, Banking and Identity Conference 25th and 26th October 2006, Storey Hall RMIT University, Melbourne. (Online).Retrived in August 2011 from < mams.rmit.edu.au/57nqr11j9s2fz.pdf >.

[23] Guay, L.L and Falkiner, S. 1980. Australian Aborigines: Shadows in a Landscape. Sydney: Globe Publishing Company.

[24] Barlow, Alex and Hill, Marjij. 1987. The Land and the Dreaming: Aboriginal Religions. Melbourne: The Macmillan Company of Australia Pty. Ltd.

[25] Lewis, Tom E and Nankivell J. 2003. Slow Tucker Long Yarn. Artwork Magazine. Issue 57 December.

[26] Demo, David H. 1992. The Self-Concept Over Time: Research Issues and Directions. Annual Review of Sociology. Vol. 18:303-326. (Online).Retrieved in August 2011 from http://www.jstor.org/stable/2083456>.

[27] Nielsen, Kai. 1987. Cultural Identity and Selfdefinition. Human Studies. Vol.10. pp. 383-390. (Online). Retrieved in August 2011 from <http://www.jstor.org/ stable/ view/ 20009009>. 